\title{
Sistem Informasi Layanan Outsourcing Tenaga Kerja Terpada Satu Pintu
}

\author{
Rafi Antareza Putra \\ Universitas Trilogi \\ Jakarta, Indonesia \\ 1108rap@gmail.com
}

\author{
Rudi Setiawan \\ Universitas Trilogi \\ Jakarta, Indonesia \\ rudi@trilogi.ac.id
}

\begin{abstract}
Penggunaan layanan outsourcing pada perusahaan perusahaan di Indonesia merupakan suatu hal yang umum dilakukan, untuk urusan pengadaan tenaga kerja tidak sedikit perusahaan yang lebih memilih layanan outsourcing dibandingkan mereka melakukan rekrutment tenaga kerja secara langsung, hal ini dilakukan dengan alasan efisiensi biaya, akan tetapi pada praktiknya tenaga kerja yang diterima tidak sesuai dengan harapan perusahaan pencari tenaga kerja hal ini didasari karena tidak adanya keterbukaan informasi mengenai calon tenaga kerja yang akan diberikan kepada perusahaan yang membutuhkan, selain itu kegiatan layanan outsourcing yang disediakan oleh perusahaan outsourcing masih dilakukan secara manual sehingga membutuhkan waktu yang cukup lama dalam hal pengurusan administrasinya. Pada penelitian ini dirancang sistem informasi layanan outsourcing tenaga kerja terpadu satu pintu guna meminimalisir kendala yang terjadi selama ini yaitu lamanya waktu penyelesaian administrasi dan tidak adanya terbukaan informasi akan tenaga kerja yang akan disalurkan. Sistem informasi layanan outsourcing tenaga kerja terpada satu pintu ini dirancang menggunakan bahasa pemrograman PHP dengan database MySQL dan Apache Web Server.
\end{abstract}

Kata kunci - Sistem Informasi, Outsourcing, Alih Daya

\section{Pendahuluan}

Alih daya atau yang biasa disebut sebagai Outsourcing dalam pengertian yang paling luas, merupakan suatu upaya yang dilakukan oleh perusahaan untuk menggunakan bantuan dari perusahaan lain dalam menunjang bisnisnya [1],[2]. Sistem outsourcing merupakan wujud dari kebijakan pasar kerja fleksibel yang disyaratkan IMF dalam pemberian bantuan pemulihan krisis ekonomi di Indonesia. [3]. Upaya alih daya seperti ini sudah menjadi hal yang umum dilakukan oleh perusahaan [4]. Terdapat beragam produk alih daya atau outsourcing yang ada di Indonesia dimulai dari penyediaan alih daya kepegawaian, ruang kerja, teknisi, alat kantor, hingga konsultan.

Proses alih daya yang dikelola oleh perusahaan outsourcing di Indonesia pelaksanaannya masih banyak dilakukan secara manual, terutama pada upaya alih daya yang mencakup pengadaan tenaga kerja. Proses manual yang dimaksud berupa proses pencatatan permohonan dan proses dokumentasi yang belum tersistem sehingga menimbulkan beberapa kelemahan yaitu pada pencarian dokumen kontrak kerjasama penyediaan jasa alih daya, selain itu kelemahan lain yang timbul adalah perusahaan pemohon alih daya tenaga kerja tidak dapat memilih sumber daya tenaga kerja yang sesuai dengan yang dibutuhkan dan bagi perusahaan yang ingin mencari layanan alih daya diperusahaan penyedia outsourcing yang belum tersistem akan memiliki tahapan yang panjang dan memerlukan waktu yang tidak sedikit, dimulai dari pencarian informasi mengenai perusahaan penyedia jasa outsourcing dan pengecekan legalitas serta track record dan reputasi yang baik.

Berdasarkan kondisi yang ada, diperlukan suatu sistem informasi yang dapat menjembatani perusahaan pencari layanan tenaga kerja dengan perusahaan penyedia jasa layanan tenaga kerja yang dapat saling terhubung secara online sehingga hal-hal yang menjadi kelemahan dalam proses yang dilakukan secara manual selama ini menjadi terhindari.

\section{TINJAUAN PUSTAKA}

\section{A. Rancang Bangun}

Rancangan bangun merupakan suatu bentuk produk yang diciptakan dari hasil penelitian untuk memudahkan penelitian dalam mengatasi permasalahan yang terdapat pada objek penelitian [5].

\section{B. Sistem Informasi}

Sistem informasi merupakan pengintegrasian unsur sistem dan unsur informasi, oleh karena itu dalam konteks tersebut, sistem informasi merupakan kumpulan dari elemen-elemen yang berinteraksi untuk menghasilkan informasi yang berguna bagi penggunanya [6].

\section{Pelayanan Terpada Satu Pintu}

Pengertian penyelenggaraan pelayanan terpadu satu pintu adalah kegiatan penyelenggaraan jasa perizinan dan non-perizinan, yang proses pengelolaannya dimulai dari tahap permohonan sampai ke tahap penerbitan ijin dokumen, dilakukan secara terpadu dalam satu tempat [7]. 
D. Alih Daya

Sistem outsourcing merupakan wujud dari kebijakan pasar kerja fleksibel yang disyaratkan IMF dalam pemberian bantuan pemulihan krisis ekonomi di Indonesia [8].

E. Data Flow Diagram (DFD)

Diagram aliran data atau data flow diagram adalah suatu diagram yang menggunakan notasi-notasi untuk arus dari data sistem, yang penggunaannya sangat membantu untuk memahami system secara logika, terstruktur dan jelas [9].

Tabel 1. Data Flow Diagram

\begin{tabular}{|c|c|c|}
\hline Gane and Sarson & Yourdon and Coad & Definisi \\
\hline 1.0 & $\begin{array}{c}1.0 \\
\text { Process }\end{array}$ & $\begin{array}{l}\text { Simbol proses simbol ini } \\
\text { menggambarkan tentang } \\
\text { proses-proses yang berada } \\
\text { pada DFD }\end{array}$ \\
\hline Data Store & Data Store & $\begin{array}{l}\text { Data store simbol yang } \\
\text { menggambarkan } \\
\text { penyimpanan data pada } \\
\text { Data flow diagrams }\end{array}$ \\
\hline $\begin{array}{l}\text { External } \\
\text { Entity }\end{array}$ & External Entity & $\begin{array}{l}\text { External entity adalah } \\
\text { entitas yang terlibat dalam } \\
\text { sebuah DFD bisa berupa } \\
\text { orang maupun sistem }\end{array}$ \\
\hline Data flow & Data flow & $\begin{array}{l}\text { Data flow atau aliran arus } \\
\text { yang menunjukan arah dari } \\
\text { sebuah data }\end{array}$ \\
\hline
\end{tabular}

\section{F. Entity Relationship Diagram}

Entity Relationship Diagram adalah simbol yang digunakan untuk menunjukkan informasi terkait hubungan antar entitas yang ada didalam sistem [10].

Tabel 2. Entity Relationship Diagram

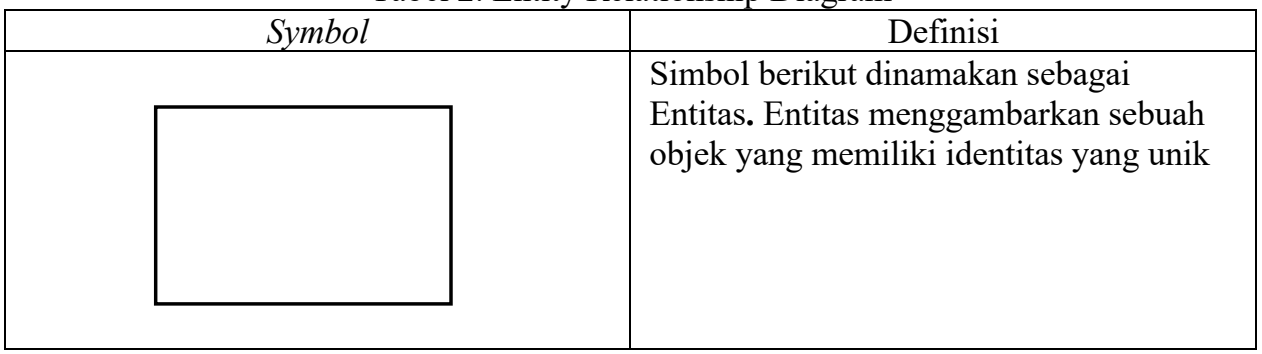




\begin{tabular}{|l|l|}
\hline & $\begin{array}{l}\text { Relasi, adalah hubungan yang mengikat } \\
\text { dua entitas atau lebih. Relasi memiliki } \\
\text { beberapa jenis yaitu, one to one, one to } \\
\text { many, many to many }\end{array}$ \\
\hline & $\begin{array}{l}\text { Atribut, adalah karakteristik atau ciri khas } \\
\text { yang dimiliki entitas ataupun relasi yang } \\
\text { merupakan detail dari masing masing } \\
\text { objek }\end{array}$ \\
\hline & $\begin{array}{l}\text { Hubungan antara entitas dengan } \\
\text { atributnya maupun dengan entitas dan } \\
\text { relasi, maupun atribut }\end{array}$ \\
\hline
\end{tabular}

\section{METODE PENELITIAN}

Metode pengembangan sistem yang digunakan pada penelitian ini adalah metode waterfall dengan tahapan proses terdiri dari analisis kebutuhan, perancangan sistem, implementasi dan pengujian sistem dan pengelolaan [11]. Metode waterfall ditunjukkan pada Gambar 1.

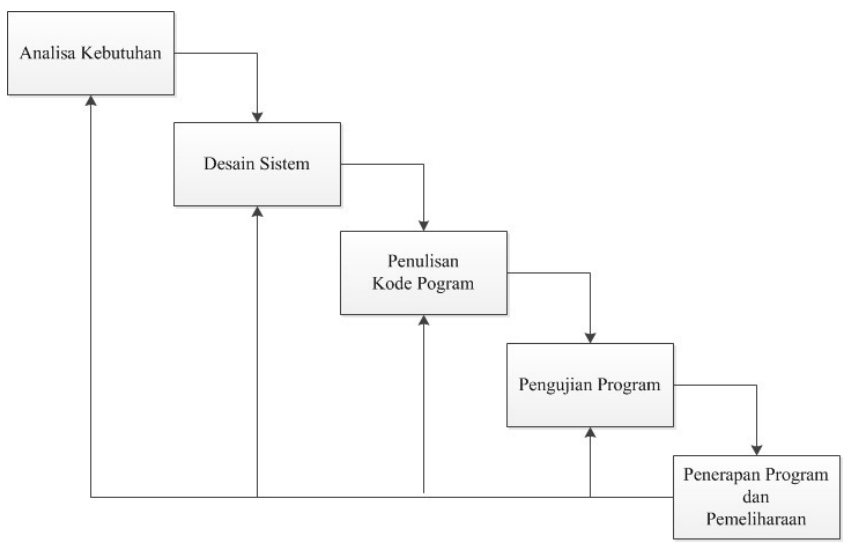

Gambar 1. Metode Waterfall

Tahap pengembangan sistem dengan metode Waterfall [12] adalah sebagai berikut :

1. Analisa kebutuhan sistem

Analisa kebutuhan sistem atau aplikasi merupakan tahapan pertama yang menjadi dasar proses pembuatan sistem. Pada tahap ini dilakukan pencarian dan pengumpulan semua kebutuhan yang diperlukan untuk menunjang kelengkapan sistem atau aplikasi, kemudian mendefinisikan semua kebutuhan yang dipenuhi dalam perangkat lunak atau aplikasi yang dibuat.

2. Desain Sistem

Desain sistem pada penelitian ini dirancang menggunakan Data Flow Diagram untuk menggambarkan bagaimana suatu sistem berinteraksi dengan aktifitas diluar sistem atau pemakai yang memiliki kepentingan atau membutuhkan suatu informasi yang dihasilkan oleh sistem.

\section{Penulisan Kode Program}

Pada penelitian ini, aplikasi ditulis dalam bahasa pemrograman Borland Delphi.

4. Pengujian Program

Pengujian program dilakukan dengan melibatkan user pengguna aplikasi, hal ini berguna untuk mendapatkan umpan balik atas pengembangan aplikasi yang telah dilakukan sehingga dapat menghasilkan aplikasi yang sesuai dengan kebutuhan penggunanya. 5. Implementasi Program dan Pemeliharaan

Implemntasi program dilakukan di koperasi taburpuja Tani Makmur Kabupaten Bantul Yogyakarta

No. 2-011/Vol. 6/2021/TechnoXplore 


\section{HASIL DAN PEMBAHASAN}

\section{A. Data Flow Diagram}

1. Diagram Context

Diagrams context merupakan diagram dasar dalam perancangan sistem berdasarkan aliran data yang didasari oleh Flowmap atau alur kerja yang sudah dibuat. Berikut rancangan diagrams context sistem usulan.

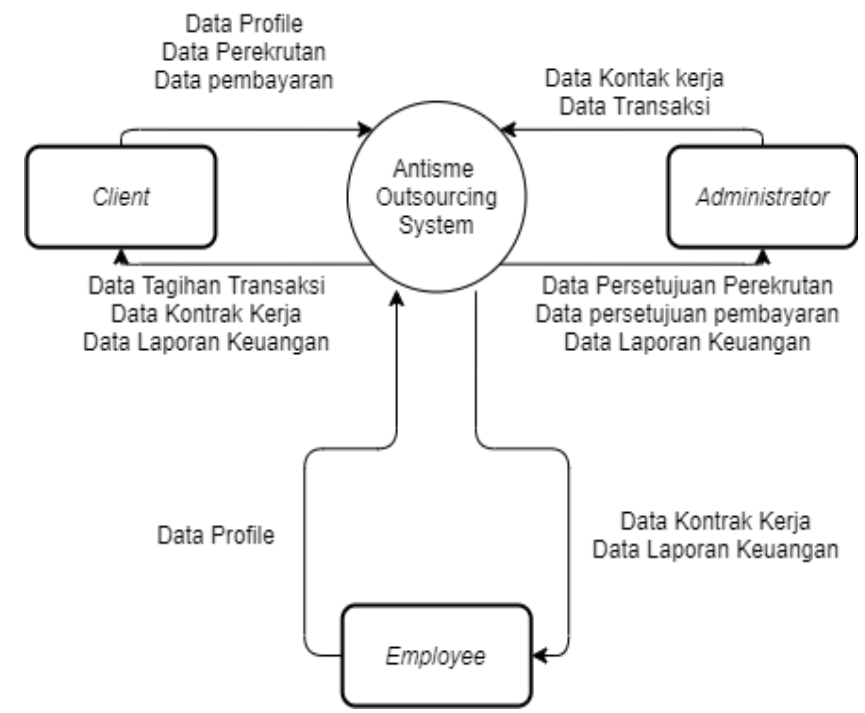

Gambar 2. Diagram Context

2. Data Flow Diagram Level 1

Pada DFD level 1 ini adalah keseluruhan proses yang memiliki enam proses diantaranya mengelola data client, mengelola data administrator, mengelola data employee, mengelola data recruitment, mengelola data laporan dan mengelola data pembayaran. Dimana input data dari proses tersebut berasal dari employe, administrator dan client serta output nya akan disimpan pada database yang didalamnya terdapat table client, account, administrator, employee,contract dan finance. 


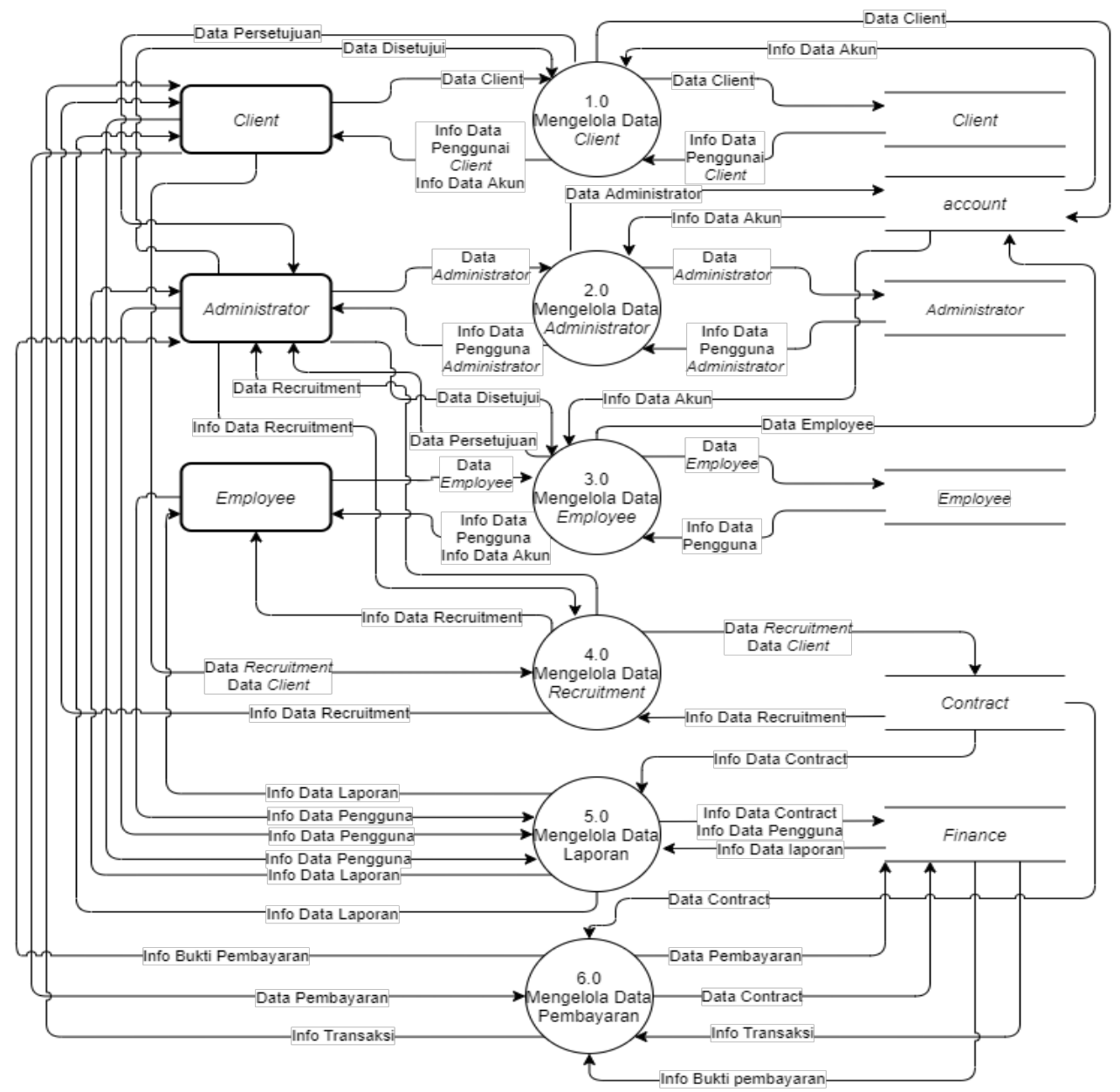

Gambar 3. DFD Level 1

3. Entity Relationship Diagram

ERD digunakan untuk menampilkan hubungan relasi antar tabel yang digunakan dalam pembuatan sistem ini. Gambar 4 menunjukkan ERD dari Sistem Informasi Layanan Outsourcing Terpada Satu Pintu. 


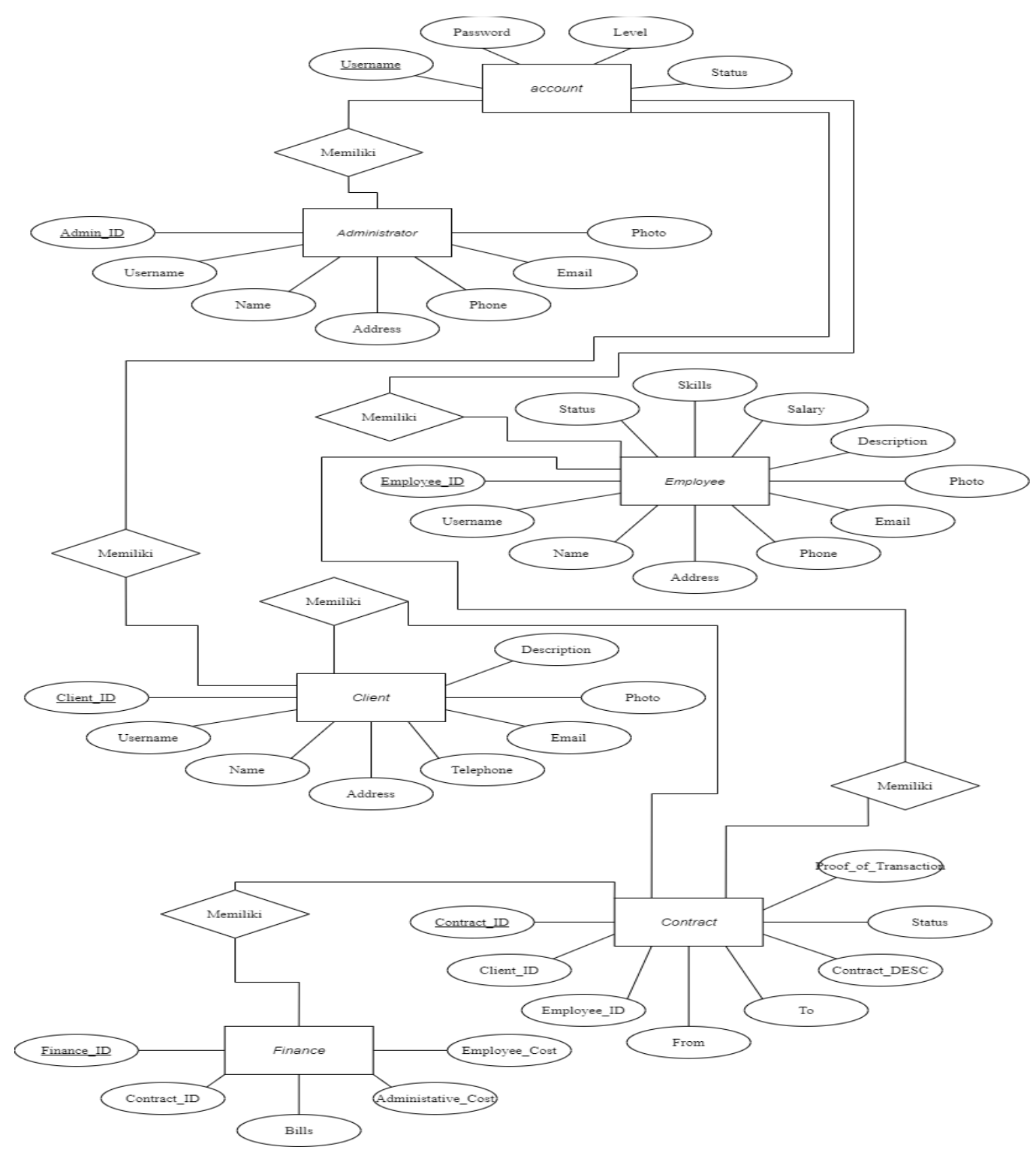

Gambar 4. Entity Relationship Diagram

\section{B. Rancangan Antarmuka}

\section{Halaman Dashboard}

Halaman Dasboard merupakan halaman utama setelah pengguna berhasil Login. Gambar 5 menunjukkan tampilan halaman dashboard bagi pengguna setelah berhasil Login kedalam aplikasi. 


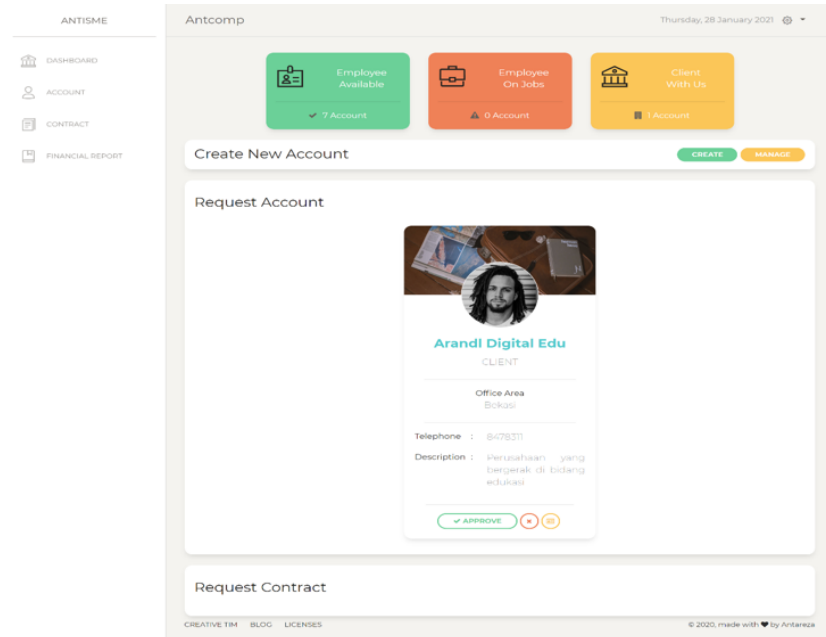

Gambar 5. Halaman Dashboard

\section{Halaman Laporan}

Halaman laporan untuk pengguna yang akan menampilkan laporan keuangan dari masing masing pengguna, Gambar 6 dan 7 menunjukkan tampilan halaman laporan.
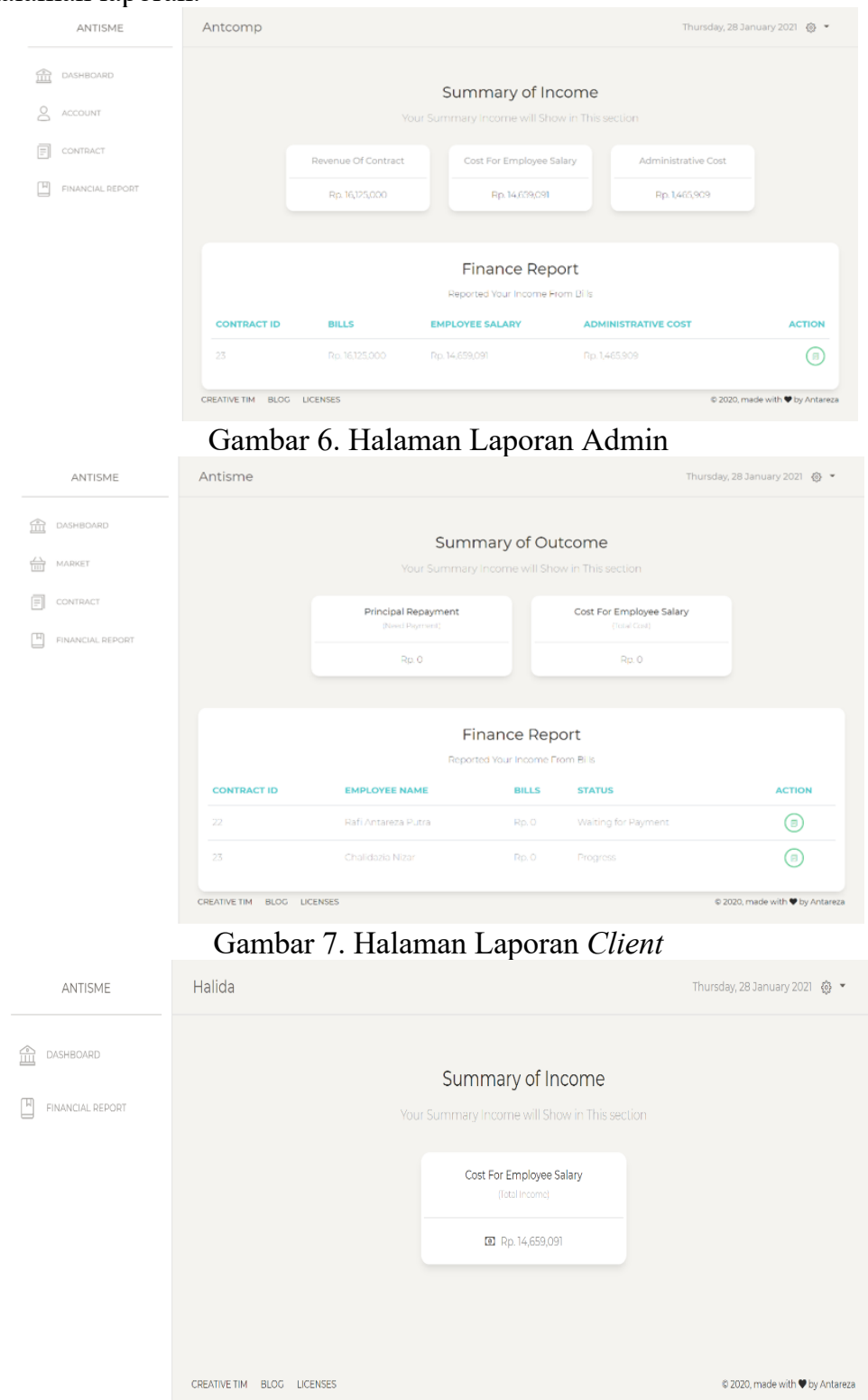


\section{Halaman List Kontrak}

Halaman list kontrak adalah antarmuka yang akan memperlihatkan kontrak-kontrak yang pernah dilakukan oleh pengguna. Gambar 9 dan Gambar 10 adalah tampilan antarmuka dari list kontrak

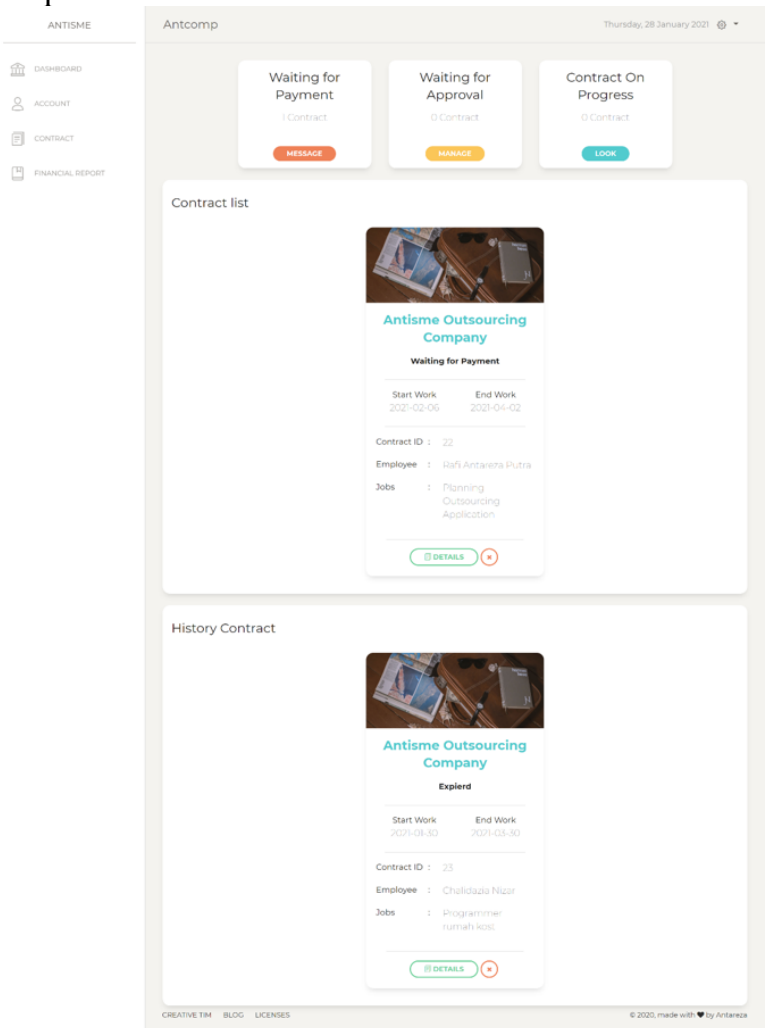

Gambar 9. Halaman List Kontrak Admin

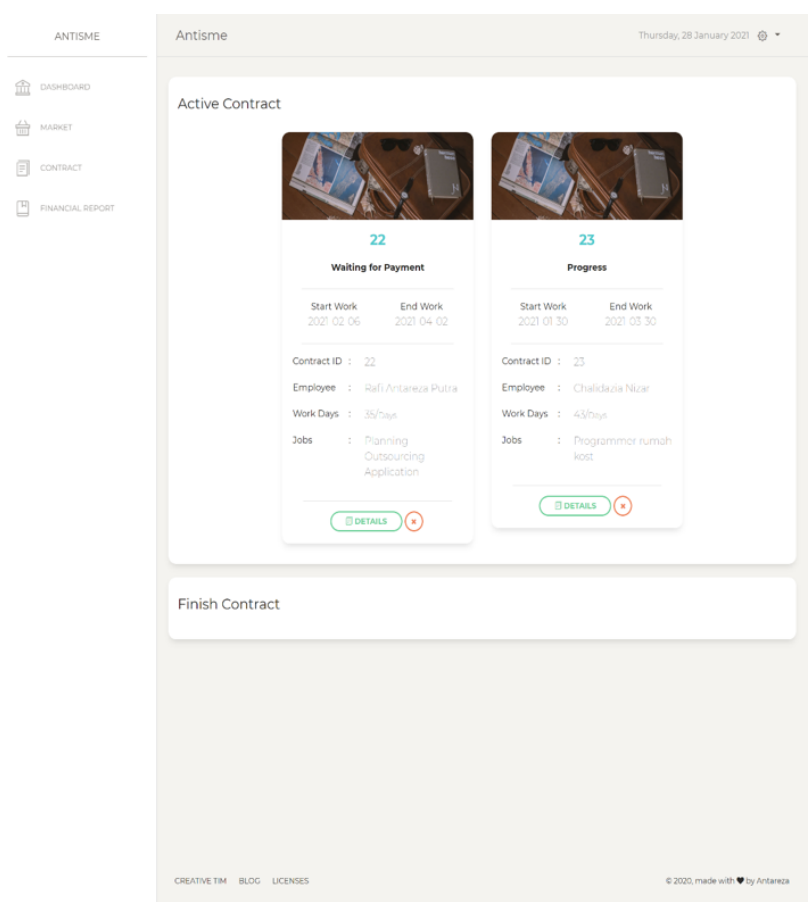

Gambar 10. Halaman List Kontrak Client

\section{Halaman Detail Transaksi}

Halaman details transaksi adalah antarmuka yang akan memperlihatkan tampilan antarmuka untuk melakukan transaksi. Gambar 11 menunjukkan tampilan antar muka details transaksi. 


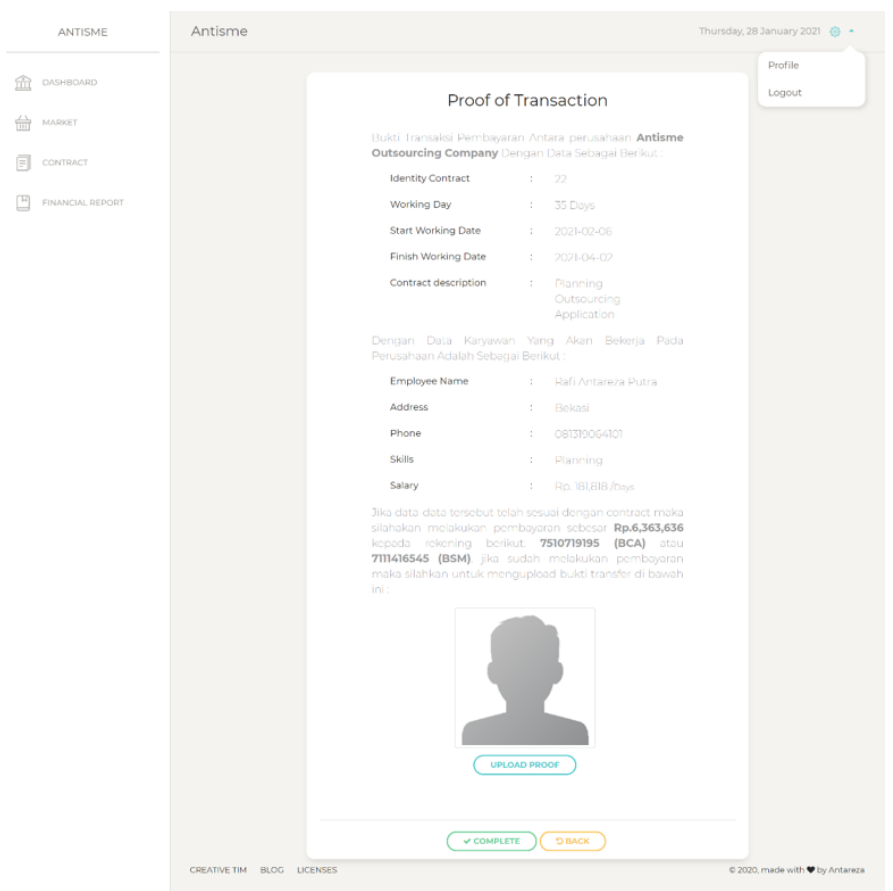

Gambar 11. Halaman Detail Transaksi

\section{KESIMPULAN}

Hasil dari keseluruhan pembahasan penulisan yang telah di uraikan, maka dapat disampaikan sebuah kesimpulan sebagai berikut :

1. Dengan adanya website outsourcing yang telah dirancang, pihak perusahaan atau yang di sebut sebagai client dapat menggunakan jasa outsourcing secara online dengan mudah, tanpa perlu datang lokasi perusahaan pihak ketiga.

2. Dengan rancangan sistem outsourcing diharapkan dapat membantu perusahaan client untuk mengelola sumber dayanya terutama pada bagian kepegawaian.

\section{DAFTAR PUSTAKA}

[1] A. A. Prabhaputra, I. N. P. Budiartha, I. P. G. Seputra, "Sistem Outsourcing Dalam Hubungan Industrial Di Indonesia (Outsourcing System In Industrial Relation In Indonesia)", Jurnal Analogi Hukum, vol. 1(1), pp. 22-27, 2019. Doi. http://dx.doi.org/10.22225/wedj.2.2.1297.44-50

[2] F. Ali, Y. Mursityo, D. Pramono, "Pengembangan Sistem Informasi Penggajian Menggunakan Zachman Framework Pada Perusahaan Outsourcing PT. Bhakti Karya Cemerlang Tangerang. Jurnal Pengembangan Teknologi Informasi Dan Ilmu Komputer, vol. 2(10), pp. 3545-3552, 2018.

[3] S. Suhartoyo, "Implementasi Fungsi Pelayanan Publik dalam Pelayanan Terpadu Satu Pintu (PTSP)," Administrative Law and Governance Journal, vol. 2(1), pp. 143-154, Jun. 2019. https://doi.org/10.14710/alj.v2i1.143-154

[4] A. P. Pattiwael, V. P. K. Lengkong, R. N. Taroreh, "Penerapan Sistem Pengupahan Karyawan Alih Daya Pada PT. Indofood Sukses Makmur TBK. Manado", Jurnal EMBA, vol. 5(2) pp. 1520-1531, Juni 2017.

[5] R. R. Fajri, P. Hambali, W. I. Rahayu, Rancang Bangun Aplikasi Penentuan dan Share Promo Produk Kepada Pelanggan Dari Website ke Media Sosial Berbasis Desktop. Bandung, Kreatif Industri Nusantara. 2020.

[6] Nafiudin, Buku Ajar Mata Kuliah Sistem Informasi Management. Surabaya, Penerbit Qiara Media. 2019.

[7] S. Suhartoyo, "Implementasi Fungsi Pelayanan Publik dalam Pelayanan Terpadu Satu Pintu (PTSP)" Administrative Law and Governance Journal, vol. 2(1), pp. 143-154, Jun. 2019. https://doi.org/10.14710/alj.v2i1.143-154

[8] A. A. M. Wijaya, "Dinamika Ketenagakerjaan Di Indonesia: Penghapusan Sistem Outsourching (Kajian Undang-Undang Nomor 13 Tahun 2003 tentang Ketenagakerjaan)", Spirit Public, vol. 12(2), pp. 94-105, 2017. Doi. https://doi.org/10.20961/sp.v12i2.16248

[9] N. I. A. G. Putri, R. Setiawan, "Rancang Bangun Aplikasi Elearning", Jurnal Sistem Informasi dan Sains Teknologi, vol. 2(1), 2020. Doi. https://doi.org/10.31326/sistek.v2i1.672

[10] A. Dennis, System Analyst and Design. Hoboken: John Wiley \& Sons. Inc. 2019.

[11] R. S. Pressman. Rekayasa Perangkat Lunak (Pendekatan Praktisi) Edisi 7 Buku 1. Yogyakarta, Andi Offset. 2012.

[12] R. Setiawan, U. A. Al Faruq, "Sistem Informasi Koperasi Taburpuja Berbasis Tanggung Renteng", Jurnal Sistem Informasi dan Sains Teknologi, vol. 1(1), 2019. Doi. https://doi.org/10.31326/sistek.v1i1.327 